\title{
THE CAMBRIDGE EQUATION WITH GOVERNMENT ACTIVITY REVISITED*
}

\author{
Ricardo Silva Azevedo Araujo ${ }^{* *}$
}

\section{Joanílio Rodolpho Teixeira ${ }^{* *}$}

\begin{abstract}
This paper offers an analysis of the steady-state distributional features found in a Kaldor-Pasinetti process, in which the government sector is allowed to run persistent deficits that may be financed through different instruments. Productive capital and bonds generate single rates of return, while workers' saving propensity remains uniform. This paper seeks to establish a generalization of Cambridge Eauqtion, considering the specific contributions of Steedman (1972), Pasinetti (1989), Dalziel (1991), and Faria (2000).
\end{abstract}

Key words: Kaldor-Pasinetti; factor income distribution; Cambridge Equation

JEL Code: D33, E12, O41

\section{A EQUAÇÃO DE CAMBRIDGE COM ATIVIDADE GOVERNAMENTAL REVISITADA}

RESUMO Neste artigo faz-se uma análise das características distributivas do processo Kaldor-Pasinetti, assumindo-se que o setor governamental incorre em persistentes déficits que podem ser financiados através de diferentes instrumentos, como

* Article received on April 24, 2009, and approved on December 13, 2010. We would like to thank John Hall for his suggestions. The usual disclaimer applies. This paper was supported in part by a grant from CNPq.

** Associate Professor, Departamento of Economics, University of Brasília, Doctor in Political Economy, University of Brasília, Phd in Political Economy, University of Sienna, Italy, e-mail: rsaaraujo@unb.br.

*** Professor, Department of Economics, University of Brasília, PhD, University of Paris 1, PanthéonSorbonne, France, e-mail: joanilioteixeira@hotmail.com. 
a emissão de títulos e de moeda. Através dessa abordagem é possível estudar como a atividade governamental afeta a distribuição de renda entre capitalistas e trabalhadores e assim obter generalizações do Teorema de Cambridge em que versões anteriores como as de Steedman (1972), Pasinetti (1989), Dalziel (1991) e Faria (2000) surgem como casos particulares.

Palavras-chave: Kaldor-Pasinetti; distribuição de renda; Teorema de Cambridge. 


\section{INTRODUCTION}

The Kaldor-Pasinetti process (K-P) could be characterized as having three groups of savers: the government plus two socioeconomic classes with differentiated propensities to save. As a socioeconomic class, capitalists save from profit income, while also exhibiting a higher propensity to save than workers, the second socioeconomic class, who are characterized as saving both from profits and wages. The government's savings behaviour is modelled symmetrically to other saving groups through fixing a constant ratio between budget deficits and disposable income, measured as net taxes of interest payments.

One of the features of this type of model is the existence of a steady-state in which the profit rate as well as the capitalist's savings behaviour, and possibly the levels of government savings and tax rates, depend only on the growth, rate of output. An alternative equilibrium could arise, however, if the system's given parameters prove to be inconsistent with the existence of capitalists. The existence of this alternative steady state has been explored by Meade (1966), Samuelson and Modigliani (1966), and Steedman (1972), showing that the alternative equilibrium could also emerge as a function of the profit rate, and that this rate is not necessarily equal to the ratio of the growth rate to the workers' propensity to save, but it could coexist with the Pasinetti equilibrium under the same savings and tax regime, along with a generalized production technology. Samuelson and Modigliani (1966) argue that Pasinetti's model could give rise to an alternative balanced growth path if "pure" capitalists would cease to exist, violating the Cambridge Equation. Their anti-Pasinetti Theorem can be seen, however, as a simple attempt to resurrect the marginal productivity theory, the condition required to attain the dual result being far from real world magnitudes [see Pasinetti (1974) and Kaldor (1966)].

If the capitalist's propensity to save (and hence their existence) is inconsistent with the level of taxation, technology and government deficits, the model could also find a solution only in the absence of that class of savers. The possibility of the Pasinetti equilibrium's inconsistency with exogenous elements of the system warrants the analysis of the necessary restrictions for a Pasinetti's steady-state, which is one of the interesting features in the literature, combined with a simple formulation of a "Cambridge Equation." 
An additional and equally important discussion involving the theorem behind the Cambridge Equation concerns the effects of government activity. Fleck and Domenghino $(1987,1990)$ have argued that the Cambridge Theorem fails to hold if there exists a steady-state budget deficit. Pasinetti (1989a, 1989b) and Dalziel (1991) ${ }^{1}$ demonstrate errors in Fleck and Domenghino's approach, while also demonstrating that Steedman's (1972) analysis could be extended to consider the budget deficit case.

This paper considers the case of a private economy in which government does not own capital goods. Section 2 provides an overview of the literature. Section 3 considers the assumption that government finances its budget deficits by selling bonds. In section 4 , the government monetizes public deficits. We seek to establish that versions of Pasinetti's Result, advanced by Steedman (1972), Pasinetti (1989a, 1989b) and Dalziel (1991), serve as particular cases of the K-P model presented in this paper. The corollary we advance is that financing a budget deficit by debt creation or by issuing money fails to alter the essence of the Cambridge Theorem.

\section{AN OVERVIEW OF THE DEBATE}

Pasinetti's model (1962) stems from Kaldor's (1955) macroeconomic theory of growth and distribution. According to the former, when workers save, they gradually become owners of financial assets. As a result, they receive both profits and wages as income. Pasinetti then shows that the equilibrium rate of profits, $r$, consistent with full employment, does not depend on workers' propensity to save, but is equal to the natural growth rate, $g_{n}$, divided by capitalists' propensity to save, $s_{c}$. This relationship between and among variables is known as the Cambridge Equation:

$$
r=g_{n} / s_{c} \text {. }
$$

This result, also termed the "Pasinetti Paradox" by Samuelson and Modigliani (1966), was derived through considering the long-runsteady-state equilibrium for a closed economy without government, and it assumes that capitalists' marginal propensity to consume is greater than that of workers. Subsequently:

$$
s_{c}>I / Y>s_{w}
$$


where $I$ stands for investment and $Y$ for production. Rewriting this inequality in the form of $s_{w}=I / Y$, Meade (1966), as well as Samuelson and Modigliani (1966), concluded that the "Cambridge Result" provided a possible steady-state solution, and not the most general solution. According to these contributors, the dual result, that is, the anti-Pasinetti equilibrium, also appears and stands fully symmetric to the Cambridge Equation.

However, Meade's attack has limited significance, since the anti-Pasinetti equilibrium holds only in the case where the steady-state solution implies the capitalists' euthanasia. Following Pasinetti (1974, p. 130), “[i]f capitalists were not to exist anymore, their propensity to save obviously could not determine the rate of profit. There is therefore a way of preventing the Cambridge Equation from operating, and that is by eliminating capitalists from the system."

After this initial debate, the focus on the Cambridge Equation shifted toward an analysis of its validity when considering government taxation and spending activities. Steedman (1972, p. 138) has shown that in this case a Pasinettian equilibrium emerges, in which the rate of profit is not dependent upon production methods. By considering a perfectly balanced government budget, Steedman arrived at the following version of the Cambridge Theorem:

$$
r=\frac{g_{n}}{s_{c}\left(1-t_{p}\right)}
$$

where $0<t_{p}<1$ is the (average and marginal) tax rate on profits.

Steedman's extension involves direct taxation and a balanced budget, holding on to the general thrust and reflecting the essence of the original Cambridge Theorem. Namely, the propensity for savings on the part of capitalists proves to be the key for determining the rate of profit. Fleck and Domenghino $(1990,1987)$ challenged Steedman's view, arguing that his contribution remains a limited case of a perfectly balanced government budget. They also argue that, in cases of a steady-state budget deficit, the workers' propensity to save is what matters when determining rates of profit. Pasinetti (1989a, 1989b), however, counter-attacked their challenge, showing that, even in the cases of budget deficits or superavits, a more correct version of the expression should be presented as: 


$$
r=\frac{g_{n}}{\left(1-t_{p}\right) s_{c}+s_{g} t_{p}},
$$

where $s_{g}$, is the government's savings rate. Naturally, if $s_{g}<0$ or $s_{g}>0$, the equation above is still valid, with the proviso that the second term in the denominator is negative or positive, respectively. ${ }^{2}$ Here we will not be concerned with the case in which $s_{g}>0$, the case of government permanent superavit.

This debate seems to have been settled. However, a minor disagreement arose between those who defended the Cambridge Equation. On one side of the debate, Denicolò and Matteuzzi (1990), Dalziel (1991) and Araujo (1992) have argued that equation (1) would also hold independently of government budget deficits or surpluses. In short, the government's propensity to save does not matter when determining the rate of profit, as argued by Pasinetti in expression (2). In section 3, below, we shall deconstruct and expose shortcomings that have not been addressed nor resolved, so far. This constitutes the main contribution of our paper.

\section{PUBLIC DEBT CREATION}

The economy consists of households, firms and the government. Households are divided into two classes: capitalists, whose main source of income is earnings from capital, and workers, who are mixed-income receivers. In this economy, ownerships are private. Capitalists and workers decide their own savings ratios. But the government may affect the overall savings ratio through the redistribution of income. For the sake of clarity of exposition, we shall consider an elementary version of the Kaldor-Pasinetti process in which there is direct taxation ${ }^{3}$ only. Suppose, for example, that a unique net direct tax, $t_{p}$, applies to all kinds of profit income, irrespective of it being earned by capitalists or workers. It is also reasonable to assume that the government will not pay taxes to itself. According to Dalziel (1991), the government's savings, $S_{g}$, is given by:

$$
S_{g}=T-G-r A=s_{g}\left(T-t_{p} i A\right)
$$


where $T$ stands for the total taxation, $G$ for the government's expenditures, and $A$ for the public debt in period $t$. Let us first consider a case in which the government finances its budget deficits by issuing bonds. By making $A$ the stock of government bonds, then it varies according to:

$$
\dot{A}=-S_{g}\left(T-t_{p} i A\right)
$$

We consider that $i$ is the nominal interest rate that in the absence of an expected and/or actual inflation is equal to the real interest rate $r$. In this case, expression (4) may be written as:

$$
\dot{A}=-S_{g}\left(T-t_{p} r A\right)
$$

Let us keep the assumption that capitalists finance a constant fraction $\lambda$, $0 \leq \lambda \leq 1$, of the public debt, which is the same as assuming that they finance the same proportion of government deficits each period of time. Hence, $\dot{A}_{c}=\lambda A=-\lambda s_{g}\left(T-t_{p} r A\right)$. Consequently, capitalists receive an interest payment $r \lambda A$ in every period. Assuming that interest receipts are taxed at the same rate as profits, capitalists' income may be written as:

$$
Y_{c}=\left(1-t_{p}\right)\left[r K_{c}+r \lambda A\right]
$$

In this case, their savings is:

$$
S_{c}=s_{c} Y_{c}=s_{c}\left(1-t_{p}\right)\left[r K_{c}+r \lambda A\right]
$$

As long as a fraction $\lambda$ of the budget deficits is financed by capitalists in each period of time, the capitalists' investment $I_{c}$, is given by:

$$
I_{c}=s_{c} Y_{c}+\lambda(T-G-r A)=s_{c}\left(1-t_{p}\right)\left[r K_{c}+r \lambda A\right]+\lambda s_{g}\left(T-t_{p} r A\right)
$$

Since capitalists invest in capital as well as government bonds, therefore: $I_{c}=\dot{K}_{c}+\dot{A}_{c}$. This identity is also limited by their budget constraint, namely:

$$
\dot{K}_{c}+\dot{A}_{c}=s_{c} r\left(1-t_{p}\right)\left[K_{c}+\lambda A\right]+\lambda s_{g}\left(T-t_{p} r A\right)
$$


Dividing both sides of (9) by $K_{c}$, we obtain:

$$
\frac{\dot{K}_{c}}{K_{c}}+\frac{\dot{A}_{c}}{A_{c}} \frac{A_{c}}{K_{c}}=s_{c} r\left(1-t_{p}\right)\left[1+\lambda \frac{A}{K_{c}}\right]+\lambda s_{g}\left[\frac{T}{K_{c}}-r t_{p} \frac{A}{K_{c}}\right]
$$

In a steady-state, the growth rate of capital and government bonds remains constant, namely $\frac{\dot{K}_{c}}{K_{c}}=\frac{\dot{A}_{c}}{A_{c}}=g_{n}$. Noticing that $A_{c}=\lambda A$, equation (10) can be rewritten as:

$$
g_{n}(1+\alpha \lambda)=s_{c} r\left(1-t_{p}\right)(1+\lambda \alpha)+\lambda s_{g} \tau-\lambda s_{g} r \alpha t_{p}
$$

where $\alpha=\frac{A}{K_{c}}$ and $\tau=\frac{T}{K_{c}}$. After some algebraic manipulation, we could derive an extended version of the Cambridge Equation as:

$$
r=\frac{g_{n}(1+\alpha \lambda)-\lambda s_{g} \tau}{\left(1-t_{p}\right) s_{c}(1+\alpha \lambda)-\lambda \alpha s_{g} t_{p}}
$$

Note that if $\lambda=0$, that is, when only workers own government bonds, we obtain the Steedman's (1972) version of the Cambridge Equation with government. If a particular fraction of the budget deficits or surpluses are financed or invested by capitalists, then we obtain Pasinetti's (1989a, 1989b) version of the Cambridge Result. The value of $\lambda$ that gives rise to Pasinetti's version is formulated in the following expression:

$$
\lambda=\frac{g_{n} t_{p}}{\tau\left[\left(1-t_{p}\right) s_{c}-s_{g} t_{p}\right]-2 g_{n} \alpha\left(1+t_{p}\right)}
$$

In conclusion, both Stedman's (1972) and Pasinetti's (1989a, 1989b) versions may well be more correctly viewed as particular cases of our approach. In our formulation, workers' savings behaviour does not play a role in the determination of the rate of profit. That is, by financing budget deficits through issuing bonds, the government fails to alter the essence of the Cambridge Equation. 


\section{MONETIZING PUBLIC DEFICITS}

Recently a number of authors, such as Commendatore (2002), Palley (1996, 2002), Park $(2002,2004,2006)$ and Seccareccia (1996), have dealt with the case in which money is introduced in the K-P framework. In this model, the existence of money may well be explained by purely transactional reasons. The general result found is that the validity of the Cambridge Equation holds independently of the way in which money is introduced in the economy. Here, let us assume that money is incorporated into the K-P process in order to monetize budget deficits. In this vein, the government does not issue government bonds, instead it monetizes budget deficits according to the following equation:

$$
G-T=-s_{g} T=\frac{\dot{M}}{p},
$$

where $M$ is the stock of money, $p$ is the price level, and real money balances are defined as $m \equiv M / p$. We assume that capitalists hold a constant fraction $\theta, 0 \leq \theta<1$ of the stock of money, thus:

$$
M_{c}=\theta M \rightarrow m_{c}=\theta m
$$

Capitalists hold their wealth in physical capital and in real money balances, therefore:

$$
\dot{K}_{c}+\dot{m}_{c}=s_{c}\left(1-t_{p}\right) r K_{c}-\theta s_{g} T+\pi m_{c}
$$

where $\pi=\frac{\dot{p}}{p}$ is the rate of inflation. In a steady-state, we have $\frac{K_{c}}{K_{c}}=\frac{\dot{m}}{m}=\frac{\dot{m}_{c}}{m_{c}}=g_{n}$, consequently, $\frac{\dot{M}}{M}=g_{n}+\pi$. Dividing both sides of (16) by $K_{c}$ yields:

$$
\frac{\dot{K}_{c}}{K_{c}}=s_{c}\left(1-t_{p}\right) r-\theta s_{g} \frac{T}{K_{c}}+\pi \frac{m_{c}}{K_{c}}-\frac{\dot{m}_{c}}{K_{c}}
$$

Rewriting (17) and considering that $\dot{m}_{c}=g_{n} m_{c}$ and $\delta=\frac{m_{c}}{K_{c}}$, we obtain:

$$
g_{n}=s_{c}\left(1-t_{p}\right) r-\theta s_{g} \tau+\pi \delta-g_{n} \delta
$$


From (18) we could then derive the Cambridge Theorem for the case in which the government monetizes the public deficits as:

$$
r=\frac{(1+\delta) g_{n}}{s_{c}\left(1-t_{p}\right)}+\frac{\theta s_{g} \tau-\pi \delta}{s_{c}\left(1-t_{p}\right)}
$$

Expression (19) keeps the essence of the Cambridge Equation despite the inclusion of monetary variables: the rate of profit is determined independently of the workers' propensity to save. If $\theta=0$, that is, if capitalists do not hold money in the steady-state equilibrium, we arrive at Faria's (2000) version of the Cambridge Result with money and inflation. However, if capitalists hold money in equilibrium, we arrive at Dalziel's (1991) version of the Cambridge Equation, where $\theta$ is given by the following expression:

$$
\theta=\frac{g_{n}(\pi-\delta)-\pi \delta}{s_{g}-\tau}
$$

Therefore, equation (19) can be seen as a more general version of the Cambridge Equation when the government monetizes public deficits. An interesting property that arises from this analysis is that money is not superneutral, since the rate of monetary expansion has effects over the long run capital stock of the economy and functional distribution of income. It is worth to remember that, by performing his analysis in a Neoclassical model, Sidrauski (1967) has found that money is super-neutral. In addition, this new version keeps the essence of the Cambridge Theorem since workers' propensity to save does not matter when determining the rate of profit.

\section{CONCLUDING REMARKS}

In this paper, through modelling an economy in which government budget deficits - or superavits - is either financed or invested by capitalists and/ or workers, we have derived a new version of the Cambridge Equation. When public deficits are totally financed by workers, the model generates the Steedman's (1972) version of the Cambridge Result. When capitalists hold part of the government bonds, we obtain Pasinetti's (1989a, 1989b) version. If the public deficits are monetized, we arrive at Faria's (2000) ver- 
sion of the Cambridge Equation, with money and the rate of inflation derived for the case in which capitalists fail to hold money in a steady-state. Dalziel's (1991) case is obtained if and when capitalists hold money in equilibrium. Finally, it should be stressed that the government's decisions regarding the financing of a budget deficit through debt creation or issuing money fails to alter the essence of the Cambridge Equation. This result reinforces previous positions by Dalziel (1989), Pasinetti (1989a,1989b), Denicolò \& Matteuzi (1990), Araujo (1992) and Teixeira (1999), who have shown that the validity of a version of the Cambridge Theorem is not limited to the case of balanced budget.

\section{NOTES}

1. Bortis (1993, p. 115) concludes that "the debate provoked by Fleck and Domenghino (1990) has been largely settled by a 'generalization and a simplification of the Cambridge Theorem with budget deficits' (Dalziel 1991).” The expressions Cambridge Theorem, Cambridge Result, Pasinetti's and Cambridge Equation are interchangeable.

2. As a consequence, expression (1) appears to be a particular case of a balanced budget, in which $s_{g}=0$.

3. Pasinetti (1989) and O'Connel (1995) deal with a more complex arrangement, since their approaches consider both direct and indirect taxes.

\section{REFERENCES}

ARAUJO, J. (1992) "The government sector in Kaldor-Pasinetti models of growth and income distribution," Journal of Post-Keynesian Economics, v. 15, n. 2, p. 211-228.

BORTIS, H. (1993) “Notes on the Cambridge Equation," Journal of Post-Keynesian Economics, v. 16, p. $105-126$.

COMMENDATORE, P. (2002) "Inside debt, aggregate demand and the Cambridge Theory of Distribution: a note," Cambridge Journal of Economics, v. 26, n. 2, p. 269-274.

DALZIEL, P. (1991) "A generalisation and simplification of the Cambridge Theorem with budget deficits," Cambridge Journal of Economics, v. 15, p. 287-300.

(1991-92) "Does government activity invalidate the Cambridge Theorem? a reconciliation," Journal of Post-Keynesian Economics, v. 14, n. 2, p. 225-231.

Denicolò, V.; MATTeuZI, M. (1990) "Public debt and the Pasinetti Paradox," Cambridge Journal of Economics, v. 14, p. 339-344.

FARIA, J. (2000) "A two-class fiscal and monetary growth model," Structural Change and Economic Dynamics, v. 11, n. 3, p. 355-364.

FLECK, F.; DOMENGHINO, C. (1987) “Cambridge (U.K.) versus Cambridge (Mass.): a Keynesian solution of the 'Pasinetti's Paradox,'” Journal of Post-Keynesian Economics, v. 10, p. 22-36. 
(1990) "Government activity does invalidate the 'Cambridge Theorem of the Rate of Profit," Journal of Post-Keynesian Economics, v. 12, p. 487-497.

KALDOR, N. (1955) “Alternative theories of distribution," Review of Economic Studies, v. 23, p. $83-100$.

(1966). "Marginal productivity and the macro-economic Theories of Distribution: comments on Samuelson and Modigliani," Review of Economic Studies, v. 38, p. 309-319.

O'CONNELL, J. (1995) “Indirect taxes and the Cambridge model," Journal of Post-Keynesian Economics, v. 18, p. 141-151.

PALLEY, T. (1996) "Inside debt, aggregate demand, and the Cambridge Theory of Distribution," Cambridge Journal of Economics, v. 20, n. 4, p. 465-474.

. (2002) "Financial institutions and the Cambridge Theory of Distribution," Cambridge Journal of Economics, v. 26, n. 2, p. 275-277.

PARK, M.-S. (2002) "Growth and income distribution in a credit money economy: introducing the banking sector in the linear production model," Cambridge Journal of Economics, v. 26 , n. 5 , p. 585-612.

PARK, M. (2004) “Credit money and Kaldor's 'Institutional' Theory of Income Distribution,” Review of Political Economy, v. 16, n. 1, p. 79-99.

. (2006). "The financial system and the Pasinetti Theorem," Cambridge Journal of Economics, v. 30, n. 2, p. 201-217.

PASINETTI, L. (1974). Growth and Income Distribution. Essays in Economic Theory. Cambridge: Cambridge Univesity Press.

. (1989a) "Ricardian debt/taxation equivalence in the Kaldor theory of profits and income distribution," Cambridge Journal of Economics, v. 13, p. 25-26.

. (1962) "Rate of profit and income distribution in relation to the rate of economic growth,” Review of Economic Studies, v. 29, p. 267-279.

. (1989b) "Government deficit spending is not incompatible with the Cambridge Theorem of the rate of profit: a reply to Fleck and Domenghino," Journal of Post-Keynesian Economics, v. 11, n. 4, p. 641-647.

SAMUELSON, P; MODIGLIANI, F. (1966) “The Pasinetti paradox in neoclassical and more general models," Review of Economic Studies, v. 33, p. 269-301.

SECCARECCIA, M. (1996) “Post-Keynesian fundism and monetarism circulation," in G. Delaplace and E. Nell (eds.). In: Money in Motion: the Post Keynesian and Circulation Approaches, London: Macmillan, p. 400-416.

SIDRAUSKI, M. (1967). "Rational choices and patterns of growth in a monetary economy," American Economic Review, v. 57, n. 2, p. 534-544.

STEEDMAN, I. (1972) “The state and the outcome of the Pasinetti process," Economic Journal, v. 82 , p. $1387-1395$.

TEIXEIRA, J. (1999) "Growth and stability in Kaldor-Pasinetti models with taxation and public expenditure," Revista de Economia Contemporânea, v. 5, p. 71-91. 